\title{
触 New Disease Reports \\ First record of a Hop stunt viroid variant associated with gumming and stem pitting on Citrus volkameriana trunk rootstock in Egypt
}

\author{
A.R. Sofy ${ }^{1 *}$ and K.A. El-Dougdoug ${ }^{2}$ \\ ${ }^{1}$ Botany and Microbiology Department, Faculty of Science, Al-Azhar University, 11884 Nasr City, Cairo, Egypt ; ${ }^{2}$ Virology \\ Laboratory, Agricultural Microbiology Department, Faculty of Agriculture, Ain Shams University, 11241 Cairo, Egypt
}

*E-mail: ahmd_sofy@yahoo.com

Received: 14 Dec 2013. Published: 09 Sep 2014. Keywords: Citrus viroid II (CVd-II), cachexia

Citrus fruits are traditional agricultural products in Egypt. Citrus volkameriana is the best rootstock for growing citrus in Egypt's desert areas (newly reclaimed land). It is far superior to other rootstocks used in Egypt in its resistance to Citrus tristeza virus as well as its tolerance to drought. Constraints to fruit production are mainly related to tree decline caused by infection with viroids (Hadidi et al., 2003). Citrus variants of Hop stunt viroid (HSVd) with the pathogenicity determinants of cachexia have been reported associated with gummy bark disease affecting sweet orange in Egypt (Sofy et al., 2010).

In 2008, gumming and stem pitting were observed on the trunk of $C$. volkameriana rootstocks grafted with Valencia sweet orange in citrus orchards in South Sinai, Behera, Monufia and Ismailia governorates. About 75 percent of the rootstocks showed these symptoms. By removing the bark under the bud union, the phloem tissue of the trunk of the $C$. volkameriana rootstock was found to be impregnated with gum. Also, conoid pits were observed in the cambial face of the wood of the rootstock due to the suppression of xylem tissue formation at these points (Figs. 1, 2). Neither gumming nor stem pitting was seen on the sweet orange scion (Fig. 1).

Bud sticks and leaf samples of Valencia sweet orange scions growing on $C$. volkameriana rootstocks were collected. These samples were from 70 trees with gumming and stem pitting symptoms and from ten trees of the same cultivar with no symptoms on the same rootstock growing in close proximity. The samples were indexed for viroids by graft-inoculation of $\mathrm{cv}$. 'Etrog' citron (Citrus medica) propagated on sour orange rootstock. Within three months, viroid leaf symptoms (petiole wrinkle and mid-vein browning) were observed on 'Etrog' citron using samples from the 70 symptom-bearing trees. No symptoms were observed on citron inoculated with samples from the ten trees without symptoms.

Sequential polyacrylamide gel electrophoresis (Semancik, 1991), under native and denaturing conditions was done with nucleic acid preparations enriched for viroid-like RNA extracted from ten 'Etrog' citron plants with symptoms. The results indicated the presence of circular, low molecular weight viroid-like RNA in all samples. Based on the RNA electrophoretic

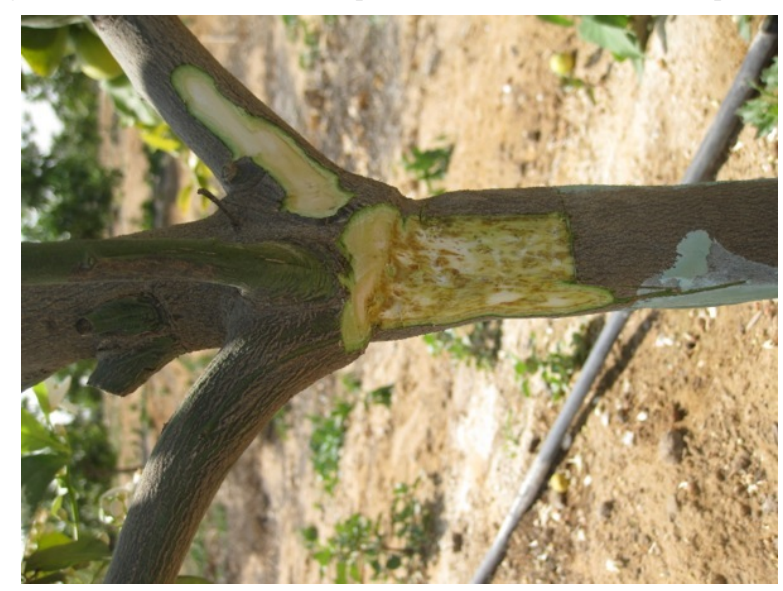

patterns additional viroid species may have been present in some of the samples. However, additional experiments would be required for their identification. 'Etrog' citron plants inoculated with healthy field trees gave negative results with electrophoresis. The ten positive samples were used in RT-PCR using a set of HSVd-specific primers (El-Dougdoug et al., 2010). Amplicons of $\sim 300 \mathrm{bp}$ were obtained in all the samples with the HSVd primers. In order to distinguish between cachexia and non-cachexia inducing variants, gel-purified RT-PCR product of the viroid was cloned in the EcoRI site of pGEM ${ }^{\circledR}-\mathrm{T}$ vector (Promega), then sequenced (GenBank Accession No. KM203115). CVd-II from diseased C. volkameriana trees is 295 nucleotides in length and shares 100\% identity with CVdIIc or Ca905 (AF131250; Reanwarakorn \& Semancik, 1999). This is the first record of Hop stunt viroid associated with gumming and stem pitting on $C$. volkameriana in Egypt.

\section{References}

El-Dougdoug KhA, Osman ME, Hayam SA, Rehab AD, Reham ME, 2010. Biological and molecular detection of HSVd - infecting peach and pear trees in Egypt. Australian Journal of Basic and Applied Sciences 4, 19-26.

Hadidi A, Flores R, Randles JW, Semancik JS, eds, 2003. Viroids.

Collingwood, Australia: CSIRO Publishing.

Reanwarakorn K, Semancik JS, 1999. Correlation of Hop stunt viroid variants to cachexia and xyloporosis diseases of citrus. Phytopathology $\mathbf{8 9}$, 568-574. http://dx.doi.org/10.1094/PHYTO.1999.89.7.568

Semancik JS, 1991. Viroid purification and characterization. In: Roistacher CN, ed. Graft-transmissible diseases of citrus: Handbook for detection and diagnosis. Rome, Italy: FAO, 233-248.

Sofy AR, Soliman AM, Mousa AA, Ghazal SA, El-Dougdoug KA, 2010. First record of Citrus viroid II (CVd-II) associated with gummy bark disease in sweet orange (Citrus sinensis) in Egypt. New Disease Reports 21, 24. http://dx.doi.org/10.5197/j.2044-0588.2010.021.024

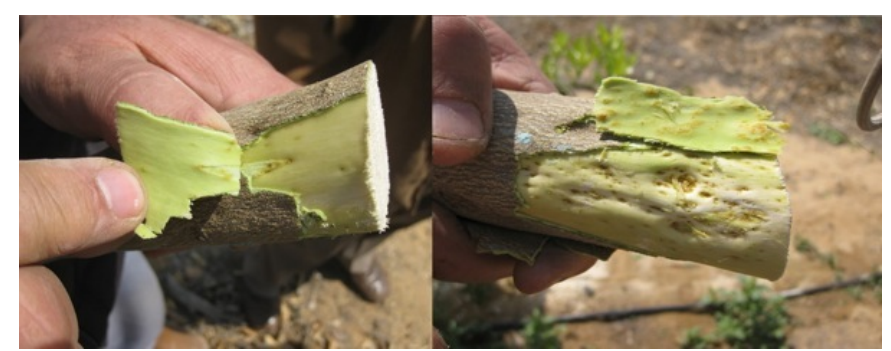

Figure 2

Figure 1

To cite this report: Sofy AR, El-Dougdoug KA, 2014. First record of a Hop stunt viroid variant associated with gumming and stem pitting on Citrus volkameriana trunk rootstock in Egypt. New Disease Reports 30, 11. http://dx.doi.org/10.5197/j.2044-0588.2014.030.011

(c) 2014 The Authors

This report was published on-line at www.ndrs.org.uk where high quality versions of the figures can be found. 